\title{
OPTIMASI RESPON PADA PERCOBAAN FAKTORIAL DENGAN MENGGUNAKAN METODE PERMUKAAN RESPON
}

\author{
FALIN TRISTANTI AYU, IZZATI RAHMI HG, YUDIANTRI ASDI \\ Program Studi Matematika, \\ Fakultas Matematika dan Ilmu Pengetahuan Alam, Universitas Andalas, \\ Kampus UNAND Limau Manis Padang, Indonesia. \\ email :falintristanti@yahoo.com
}

\begin{abstract}
Abstrak. Metode Permukaan Respon atau Response Surface Methodology adalah gabungan dari teknik matematika dan statistika yang digunakan dalam pemodelan dan analisis dimana respon yang diamati dipengaruhi oleh sejumlah variabel. Metode permukaan respon digunakan untuk mencari taraf-taraf peubah bebas yang dapat mengoptimalkan respon. Dengan metode ini dapat diketahui model empirik yang menyatakan hubungan antara variabel-variabel independen dengan variabel respon, serta dapat diketahui nilai variabel-variabel independen yang menyebabkan nilai variabel respon menjadi optimal. Eksperimen dengan metode permukaan respon dilakukan dalam dua tahap yaitu eksperimen tahap I dan eksperimen tahap II. Desain eksperimen yang digunakan pada eksperimen tahap I adalah desain faktorial dua level sedangkan desain eksperimen yang digunakan pada eksperimen tahap II adalah Central Composite Design (CCD). Tahapan dalam metode permukaan respon pada intinya yaitu mencari fungsi aproksimasi yang menyatakan hubungan antara variabel independen dengan variabel respon, mengestimasi parameter-parameter dari fungsi aproksimasi yang diperoleh dengan metode kuadrat terkecil dan selanjutnya dilakukan analisis pengepasan permukaan. Karakteristik permukaan respon digunakan untuk menentukan apakah jenis titik stasionernya maksimum, minimum atau titik pelana. Prosedur pengujian yang dilakukan dalam metode permukaan respon diantaranya uji kesesuaian model regresi (lack of fit), uji parameter regresi secara serentak dan pengujian asumsi residual.
\end{abstract}

Kata Kunci: Desain eksperimen, Metode Permukaan Respon (Response Surface Methodology), Two Level Factorial Design, Central Composite Design (CCD)

\section{Pendahuluan}

Percobaan merupakan penyelidikan terencana untuk mendapatkan fakta baru. Bagi statistikawan, percobaan adalah segugus aturan yang digunakan untuk memperoleh contoh dari populasi [3]. Tujuan suatu percobaan adalah untuk mendapatkan informasi yang maksimum tentang peubah-peubah bebas yang mempengaruhi respon [3]. Peranan statistika dalam penelitian, terutama penelitian yang menggunakan metode percobaan, meliputi perancangan, pengumpulan data, analisis data, interpretasi hasil analisis, dan penarikan kesimpulan berdasarkan hasil analisis. Perancangan penelitian mencakup perancangan perlakuan, perancangan percobaan, dan perancangan respon. Ketiga perancangan ini merupakan langkah yang sangat penting dan perlu dipersiapkan secara terperinci sebelum percobaan dilakukan.

Pada suatu rancangan percobaan, seorang peneliti memiliki keleluasaan untuk 
melakukan pengawasan terhadap sumber-sumber keragaman. Peneliti dapat menciptakan perlakuan yang diinginkan dan mengamati perubahan-perubahan yang terjadi pada responnya. Perlakuan dapat disusun dari beberapa faktor, baik bersifat kualitatif maupun kuantitatif. Berdasarkan pada jumlah faktor penyusun perlakuan yang dicobakan, ada dua macam percobaan, yaitu percobaan satu faktor dan percobaan faktorial.

Dalam penelitian ini, akan dibahas tentang metode permukaan respon dalam menentukan kondisi optimal respon pada percobaan faktorial.

\section{Metode Penelitian}

Metode permukaan respon adalah teknik yang digunakan untuk memodelkan antara variabel bebas dan variabel respon. Metode permukaan respon atau RSM pada prinsipnya adalah teknik yang meliputi analisis regresi dan rancangan percobaan untuk menyelesaikan masalah optimasi. Adapun langkah-langkah analisa pengolahan datanya yaitu:

(1) Menentukan variabel respon dan variabel bebas yang berpengaruh terhadap respon.

(2) Membuat rancangan percobaan orde pertama.

(3) Membuat dan menguji model tersebut untuk mengetahui apakah ada variabel bebas yang berpengaruh nyata terhadap variabel respon dan untuk mengetahui ada tidaknya lack of fit dengan menggunakan analisis varians

(4) Membuat rancangan percobaan orde kedua.

(5) Membuat dan menguji model orde kedua apakah ada variabel bebas yang berpengaruh nyata terhadap variabel respon dan apakah ada atau tidaknya lack of fit dengan menggunakan analisis varians.

(6) Jika model orde kedua telah sesuai dengan data atau tidak ada lack of fit maka akan dilakukan pengujian asumsi residual.

(7) Menentukan kondisi optimum dari model yang sesuai.

(8) Menganalisa analisa kanonik untuk mempermudah penggambaran kontur dari permukaan respon.

\section{Hasil dan Pembahasan}

Data yang digunakan sebagai contoh kasus dalam penelitian ini adalah data sekunder yaitu data tentang produksi asap cair sebagai variabel respon, suhu dan lama waktu sebagai variabel bebas yang mempengaruhi produksi asap cair.

\subsection{Analisis Orde-1}

Dari rancangan percobaan akan dilakukan desain dan analisis menggunakan orde I, jumlah pengamatan dalam orde I adalah $N=2^{2}+5$ (center point), yang artinya level yang digunakan 2 yaitu level rendah yang dikodekan dengan (-1) dan level tinggi yang dikodekan dengan (+1 atau 1) dengan 2 faktor (variabel bebas atau variabel independen) ditambah dengan 5 titik pusat (center point) yang dikodekan dengan 0. Rancangan orde I dapat dilihat dalam Gambar 1 berikut : 


\begin{tabular}{|c|c|c|c|c|c|}
\hline \multirow{2}{*}{ Run } & \multicolumn{2}{|c|}{ Faktor Kode } & \multicolumn{2}{|c|}{ Faktor Aktual } & Respon \\
\cline { 2 - 6 } & $\mathrm{X} 1$ & $\mathrm{X} 2$ & Waktu (Menit) & Suhu $\left({ }^{\circ} \mathrm{C}\right)$ & Produksi $(\%)$ \\
\hline 1 & -1 & -1 & 105 & 350 & 27,5 \\
\hline 2 & 1 & -1 & 135 & 350 & 28,5 \\
\hline 3 & -1 & 1 & 105 & 450 & 29,0 \\
\hline 4 & 1 & 1 & 135 & 450 & 29,8 \\
\hline 5 & 0 & 0 & 120 & 400 & 29,9 \\
\hline 6 & 0 & 0 & 120 & 400 & 30,3 \\
\hline 7 & 0 & 0 & 120 & 400 & 30,1 \\
\hline 8 & 0 & 0 & 120 & 400 & 29,9 \\
\hline 9 & 0 & 0 & 120 & 400 & 29,9 \\
\hline
\end{tabular}

Gambar 1. Rancangan Orde-1

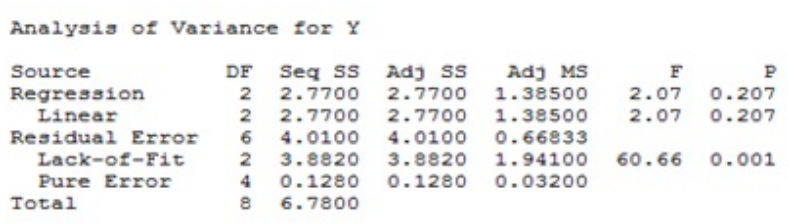

Gambar 2. Analisis Varian Model Orde-1

Dengan menggunakan taraf signifikansi (confidence level) $=0,05$, maka nilai regresi secara serentak diperoleh $p$-value $=0,207>$. Hal ini berarti tidak satupun variabel bebas yang berpengaruh nyata terhadap variabel respon. Hasil analisis varian juga menunjukkan hasil uji ketidaksesuaian model atau lack of fit yaitu $p$-value pada uji lack of fit bernilai 0,001 atau lebih kecil dari nilai $=0,05$, maka keputusannya tolak $H_{0}$ yang artinya model yang dibuat tidak sesuai dengan data.

Dari hasil analisis diatas, maka dapat disimpulkan bahwa model orde I tidak cocok untuk wilayah eksperimen dan model orde yang lebih tinggi dibutuhkan untuk analisis. Karena model orde I tidak sesuai sehingga analisis dilanjutkan pada pendugaan model orde yang lebih tinggi yaitu orde II.

\subsection{Analisis Orde-2}

Dalam rancangan orde II, pendugaan model dilakukan dengan menggunakan model kuadratik. Pada orde II, rancangan yang digunakan adalah Central Composite Design (CCD) dengan jumlah pengamatan $2^{2}+5$ (centerpoint $)+4$ (axialpoint). Untuk rancangan orde II dilakukan satu kali perulangan sehingga jumlah pengamatan menjadi 13 pengamatan. Rancangan percobaan orde II, disajikan pada Gambar 3 berikut: 


\begin{tabular}{|c|c|c|c|c|c|}
\hline \multirow{2}{*}{ Run } & \multicolumn{2}{|c|}{ Faktor Kode } & \multicolumn{2}{c|}{ Faktor Aktual } & Respon \\
\cline { 2 - 6 } & $\mathrm{X} 1$ & $\mathrm{X} 2$ & Waktu (Menit) & Suhu $\left({ }^{\circ} \mathrm{C}\right)$ & Produksi (\%) \\
\hline 1 & -1 & -1 & 105 & 350 & 27,5 \\
\hline 2 & 1 & -1 & 135 & 350 & 28,5 \\
\hline 3 & -1 & 1 & 105 & 450 & 29,0 \\
\hline 4 & 1 & 1 & 135 & 450 & 29,8 \\
\hline 5 & $-1,414$ & 0 & 98,78679656 & 400 & 28,5 \\
\hline 6 & 1,414 & 0 & 141,2132034 & 400 & 29,2 \\
\hline 7 & 0 & $-1,414$ & 120 & 329,289322 & 27,9 \\
\hline 8 & 0 & 1,414 & 120 & 470,710678 & 29,3 \\
\hline 9 & 0 & 0 & 120 & 400 & 29,9 \\
\hline 10 & 0 & 0 & 120 & 400 & 30,3 \\
\hline 11 & 0 & 0 & 120 & 400 & 30,1 \\
\hline 12 & 0 & 0 & 120 & 400 & 29,9 \\
\hline 13 & 0 & 0 & 120 & 400 & 29,9 \\
\hline
\end{tabular}

Gambar 3. Rancangan Orde-2

Hasil analisis varian dari software minitab setelah dimasukkan rancangan orde II diperoleh sesuai dengan Gambar 3 diatas:

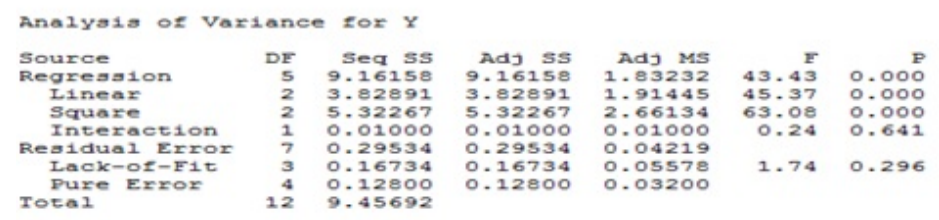

Gambar 4. Analisis Varian Model Orde-2

Persamaan model untuk orde II adalah:

$$
y=30,02+0,4932 x_{1}+0,8450 x_{2}-1,1825 x_{1}^{2}-1,4325 x_{2}^{2}-0,1 x_{1} x_{2}
$$

Seperti pengujian yang dilakukan pada orde I, pengujian hasil analisis varian orde II diatas dapat diketahui bahwa $p$-value regresi secara serentak adalah 0,000 atau kurang dari nilai $(0,05)$. Hal ini berarti ada variabel bebas yang berpengaruh nyata terhadap variabel respon. Pengujian lack of fit dilakukan sama seperti pengujian lack of fit dalam orde I. Nilai $p$ - value pada uji lack of fit adalah 0,296 atau lebih dari nilai $(0,05)$, sehingga dapat dikatakan model kuadratik pada orde II yang digunakan telah sesuai dengan data. 
Optimasi Respon Percobaan Faktorial 55

\subsection{Penentuan Titik Stasioner}

Setelah didapatkan model yang sesuai, dilanjutkan dengan penentuan titik stasioner dari model orde II sehingga diperoleh:

$$
\begin{gathered}
b=\left(\begin{array}{l}
0,680583 \\
0,249150
\end{array}\right) \\
\text { dan } \\
B=\left(\begin{array}{rr}
-0,00262778 & -0,00003333 \\
-0,00003333 & -0,0002865
\end{array}\right)
\end{gathered}
$$

Titik stasioner yang didapatkan adalah:

$$
x_{0}=-\frac{1}{2} B^{-1} b=\left(\begin{array}{c}
124,166 \\
420,372
\end{array}\right)
$$

sedangkan nilai taksiran respon pada titik stasionernya adalah:

$$
\begin{aligned}
\hat{y_{0}} & =b_{0}+\frac{1}{2} x_{0}^{t} b \\
& =-64,4298+\frac{1}{2}(124,166420,372)\left(\begin{array}{c}
0,680583 \\
0,249150
\end{array}\right) \\
& =-64,4298+\frac{1}{2}(189,2408) \\
& =-64,4298+94,6204 \\
& =30,1906
\end{aligned}
$$

Dari nilai titik-titik stasioner diatas, maka diperoleh titik optimalnya yaitu waktu $\left(x_{1}\right)=124,166$ menit dan suhu $\left(x_{2}\right)=420,372^{\circ} \mathrm{C}$ dan respon optimalnya adalah 30,1906 persen.

Untuk membantu analisis karakteristik permukaan respon, digunakan metode analisis kanonik. Dengan menghitung nilai eigen dari matrik B, yaitu: $(-0,0026283$ $-0,0002860)$.

Karena kedua nilai eigen adalah negatif, maka bentuk permukaan responnya maksimum. 


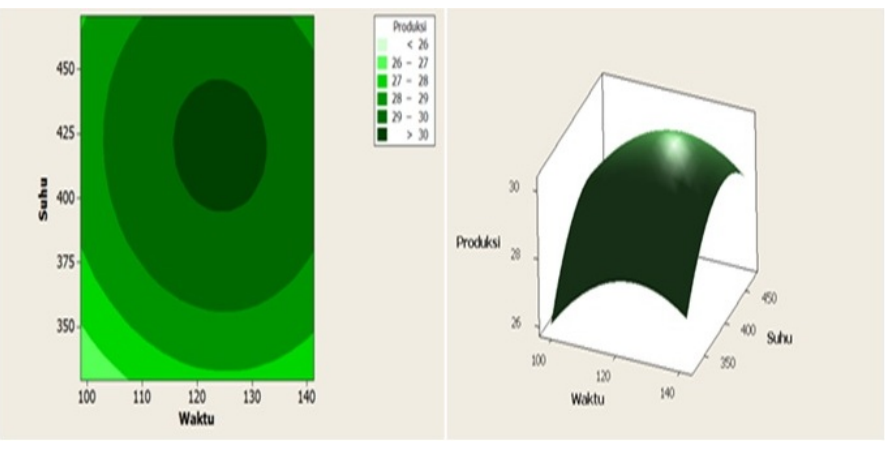

Gambar 5. Plot Contour Produksi vs Suhu, Waktu dan Plot Permukaan Respon Produksi vs Suhu, Waktu

\section{Kesimpulan}

Metode permukaan respon dapat digunakan untuk menentukan kombinasi level faktor yang menghasilkan respon optimum (titik optimum) dan menentukan nilai respon optimum. Model permukaan respon orde I dapat ditulis:

$$
y=\beta_{0}+\sum_{i=1}^{k} \beta_{i} x_{i}+\varepsilon
$$

Dalam prakteknya model orde I jarang digunakan karena hasil pengujian sering kali menunjukkan ketidaksesuaian model orde I dengan data yang digunakan. Karena model orde I sering menunjukkan ketidaksesuaian dengan data yang digunakan sehingga analisis dilanjutkan pada pendugaan model orde yang lebih tinggi yaitu model orde II. Model orde II pada metode permukaan respon dapat ditulis:

$$
y=\beta_{0}+\sum_{i=1}^{k} \beta_{i} x_{i}+\sum_{i=1}^{k} \beta_{i i} x_{i}^{2}+\sum_{i<j=2}^{k} \beta_{i j} x_{i} x_{j}+\varepsilon
$$

Penentuan titik optimal diperoleh dengan cara

$$
x_{s}=-\frac{1}{2} \hat{B}^{-1} b
$$

dengan

$$
b=\left(\begin{array}{r}
b_{1} \\
b_{2} \\
\vdots \\
b_{k}
\end{array}\right) \operatorname{dan} \hat{B}=\left(\begin{array}{cccc}
b_{11} & \frac{b_{12}}{2} & \cdots & \frac{b_{1 k}}{2} \\
b_{21} & \frac{b_{22}}{2} & \cdots & \frac{b_{2 k}}{2} \\
\ldots & \cdots & \ddots & \cdots \\
b_{k 1} & \frac{b_{k 2}}{2} & \cdots & \frac{b_{k k}}{2}
\end{array}\right)
$$

sedangkan untuk respon optimal diperoleh sebagai berikut:

$$
\hat{y_{s}}=b_{0}+\frac{1}{2} x_{s}^{t} b
$$

\section{Ucapan Terima kasih}

Penulis mengucapkan terima kasih kepada Ibu Hazmira Yozza, Bapak Dodi Devianto dan Bapak Admi Nazra yang telah memberikan masukan dan saran sehingga 
paper ini dapat diselesaikan dengan baik.

\section{Daftar Pustaka}

[1] Dean, A and Voss, D. 1999. Design and Analysis of Experiments. Springer. New York

[2] Gaspersz, V. 1991. Metode Perancangan Percobaan. CV. ARMICO. Bandung

[3] Montgomery, DC. 2001. Design and Analysis of Experiments 5th Edition. John Wiley and Sons, Inc. New York

[4] Myers, R.H, Montgomery, D.C, and Anderson, C.M. 2009. Response Surface Methodology Process and Product Optimization using Design Experiments, Third Edition. John Wiley and Sons, Inc. New York

[5] Oramahi, H.A. 2008. Teori dan Aplikasi Penggunaan RSM. Ardana Media. Yogyakarta

[6] Sastrosupadi, A. 1999. Rancangan Percobaan Praktis Bidang Pertanian Edisi Revisi. Kanisius. Yogyakarta

[7] Gaspersz, V. 1992. Teknik Analisis dalam Penelitian Percobaan. Tarsito. Bandung 